\title{
CORRELATION BETWEEN RADIOACTIVE CESIUM AND THE INCREASE OF PANCREATIC CANCER: A HYPOTHESIS
}

\author{
S. Venturi \\ Department of Health. Emilia-Romagna Region. Pennabilli (Rimini), Italy. \\ Email: dr.venturi.sebastiano@gmail.com \\ Received: 27 Aug. 2020; accepted: 24 Nov. 2020
}

Worldwide, both the incidence and death rates of pancreatic cancer (PC) are increasing. While the exact cause of PC is not known, certain risk factors are associated with the disease, including tobacco smoking, obesity and diabetes. The present author studied associations between radioactive cesium $\left({ }^{137} \mathrm{Cs}\right)$ and increases in PC. There is a correlation between the geographical map of the incidence of and mortality from PC and the map of nuclear plants, related nuclear accidents and nuclear tests with consequent radioactive fallout, of which ${ }^{137} \mathrm{Cs}$, with its half-life of about 30 years, is one of the most relevant components. Published data in medical literature at World, European and Italian levels are reviewed and compared. In human and animal bodies, cesium ions behave like potassium ion $\left(\mathrm{K}^{+}\right)$. Cs $\mathrm{s}^{+}$is absorbed from plants and fruit competitively with $\mathrm{K}^{+}$ and is localized mainly inside cells. ${ }^{137} \mathrm{Cs}$ is present in the environment for at least 10-20 times its half-life, i.e. about 300-600 years. Autoradiographic studies in mice have shown that ${ }^{137} \mathrm{Cs}$ is concentrated in significant quantities in the pancreas, in particular in exocrine cells, where most PCs featuring high malignancy originate. The pancreas and the salivary glands secrete cesium into the intestine thus eliminating about $14 \%$ of absorbed Cs with the feces, whereas the remaining $86 \%$ is eliminated by kidney with the urine. Some previous studies between radioactive Cs and tumors in general have been also reported.

Key words: Radioactive Cesium, Pancreatic Cancer, Nuclear Accidents and Tests, Epidemiology.

\section{ГИПОТЕЗА О КОРРЕАЯЦИЯ МЕЖАУ ПОВЫШЕННЫМИ УРОВНЯМИ РААИОАКТИВНОГО ЦЕЗИЯ И ЗАБОАЕВАЕМОСТИ РАКОМ ПОАЖЕИУАОЧНОЙ ЖЕАЕЗЫ}

\author{
С. Вентури \\ Отдел здравоохранения, Регион Эмилия-Романья, Пеннабилли (Римини), Италия \\ Эл.nочma: dr.venturi.sebastiano@gmail.com
}

Заболевवемость раком поджелудочной железы (РПЖ) и смертность от него растүт по всему миру. Точные причины РПЖ неизвестны, а некоторые факторы риска включают күрение, оба типа диабета и ожирение. В настоящей работе исследована корреляция межАУ радиоактивным цезием повышением РПЖ. Сүществует связь между географическим распределением заболеваемости РПЖ и смертности от него и расположением атомных электростанций, аварий с ними, проведенных яАерных испытаний и радиосктивными осадками, в составе которых ${ }^{137} \mathrm{Cs}$ с его периодом Полүраспада около 30 Ает является оАним из самых заслуживающих внимания компонентов. Рассмотрены и сопоставлены соответствующие данные, опүбликованные в мире, Европе и Италии. Ионы цезия в организме человека и животных веАүт себя поАобно ионам калия ( $\left.\mathrm{K}^{+}\right)$, постүпая из растений конкүрентно по отношению к калию $\mathrm{b}$ локализуясь главным образом в клетках. ${ }^{137}$ Сs заметен в среде в течение времени примерно (10-20)-кратном относительно периоАа его полураспада, то есть около 300-600 Ает. Авторадиографические исследования на мышах показали, что ${ }^{137} \mathrm{Cs} \mathrm{концентрируется} \mathrm{в} \mathrm{тканях} \mathrm{поджелуАочной} \mathrm{железы,}$ особенно в экзокринных клетках, от которых происходят наиболее злокачественные клетки РПЖ. ПоджелуАочная железа и слюнные железы выАеляют цезий в кишечник, так что $14 \%$ оказываются в фекалиях, тогАа как остальные 86 выделяются почками с мочой. Имеются публикации о связи радиоактивного цезия и опүхолями в целом.

Ключевые слова: радиоактивный цезий, рак поджелудочной железы, ядерные испытания, эпидемиология

\section{INTRODUCTION}

Worldwide, both the incidence and death rates of pancreatic cancer (PC) are increasing (Fig. 1).

$\mathrm{PC}$ is the seventh leading cause of global cancer deaths in industrialized countries and the third most common cancer in the USA. Based on GLOBOCAN 2018 estimates, PC has been ranked as the $11^{\text {th }}$ most common cancer in the world counting 458,918 new cases and causing 432,242 deaths ( $4.5 \%$ of all deaths caused by cancer) in 2018 . Worldwide incidence and mortality of PC correlate with increasing 


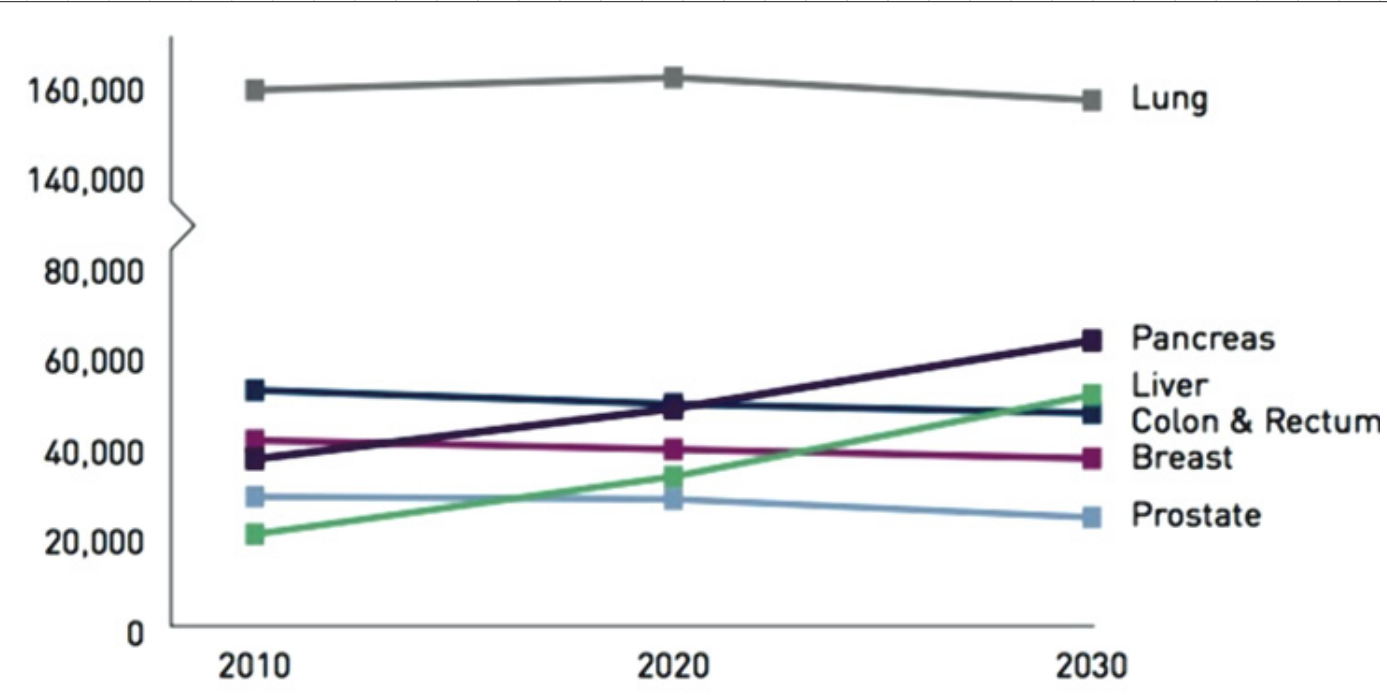

Fig. 1. Temporal trends of deaths caused by the most frequent cancers and their forecast in the world from 2010 to 2030 [24].

age and is slightly more common in men than in women. Despite advancement in the knowledge of potential risk factors that cause PC and in newly available tools for early diagnosis, its incidence is estimated to increase and will include 355,317 new cases up to the year 2040 in U.S. $[1,8]$. Moreover, death rate may increase more than that of other cancers because PC, at difference from many other cancers, is still incurable. While the exact cause of $\mathrm{PC}$ is not known, certain risk factors associated with the disease include tobacco smoking, obesity and both types of diabetes mellitus [24]. The present paper will provide evidence that the increasing PC may also be contributed by radioactive cesium.

\section{Causes of pancreatic cancer}

The exact cause of PC causes is not known. General risk factors include the following (Fig. 2): Age, with nearly 90 percent found among people aged 55 and older; gender, the cancer being somewhat more common in men than women; obesity; types I and II diabetes mellitus; chronic pancreatitis; liver cirrhosis, Helicobacter pylori infection, and cigarettes smoking, the latter cause attributable to almost one-third of all PC. Carcinogens (cancer-causing chemicals) found in tobacco products may damage the pancreas, and smoking may add to the risks associated with other conditions, such as long-term inflammation of the pancreas (chronic pancreatitis). About 10 percent of $\mathrm{PC}$ is thought to relate to genetic factors and mutations. However, having a risk factor, or even many, does not mean that you will get cancer [25]. Some people who get cancer may have few or no known risk factors.

Coincidences of relatively high PC prevalence with nuclear power production

The incidence of PC varies across regions and populations (Fig. 2, Fig. 3). In 2018, 458,918 new cases of PC were registered worldwide, representing $2.5 \%$ of all cancers. The age-standardized rate (ASR) incidence was highest in Europe (7.7 per 100,000 people) and North America (7.6 per 100,000 people), followed by Oceania (6.4 per 100,000 people). The lowest rate was observed in Africa with an estimated incidence of 2.2 per 100,000 people $[16,24]$. Differences in incidence rates were 30 fold between the populations featuring the highest rate (Hungary: 10.8), and the lowest rate (Guinea: 0.35). The high PC level in Oceania and Australia, where there are no power plants, is probably related to nuclear tests.

Intriguingly, the areas where both PC rates and nuclear power production are high often coincide. Higher levels of nuclear power production are prone with higher risks of accidents. Chernobyl was the most serious nuclear accident in the history of nuclear power plants. However, many other minor accidents have happened in various countries. The most important and harmful consequence of radioactivity was that caused by the release of iodine-131, which can be at work only during the first few weeks. Iodine-131 is most dangerous because it can cause cancer, particularly thyroid cancer, in people exposed to it in the shortest time [5]. The list of risk factors of carcinogenesis is very broad and constantly evolving. Carcinogenesis is multifactorial; moreover, host response capabilities, including immune defense mechanisms and DNA repair processes should be accounted for [8].

\section{Cesium from nuclear plants and accidents}

Stable (nonradioactive) cesium $\left({ }^{133} \mathrm{Cs}\right)$ is an alkali metal, which exists naturally at very low concentrations in the soil as the $\mathrm{Cs}^{+}$ion. Cs has no known beneficial function in plants; however, at high concentrations, it can cause toxicity manifested as growth inhibition. Radioactive Cs $\left({ }^{137} \mathrm{Cs}\right.$ and ${ }^{134} \mathrm{Cs}$ ), a byproduct of nuclear fission of uranium, 
A

- Male Reases In Femalo Ranes Cases II Femalo Cases

B

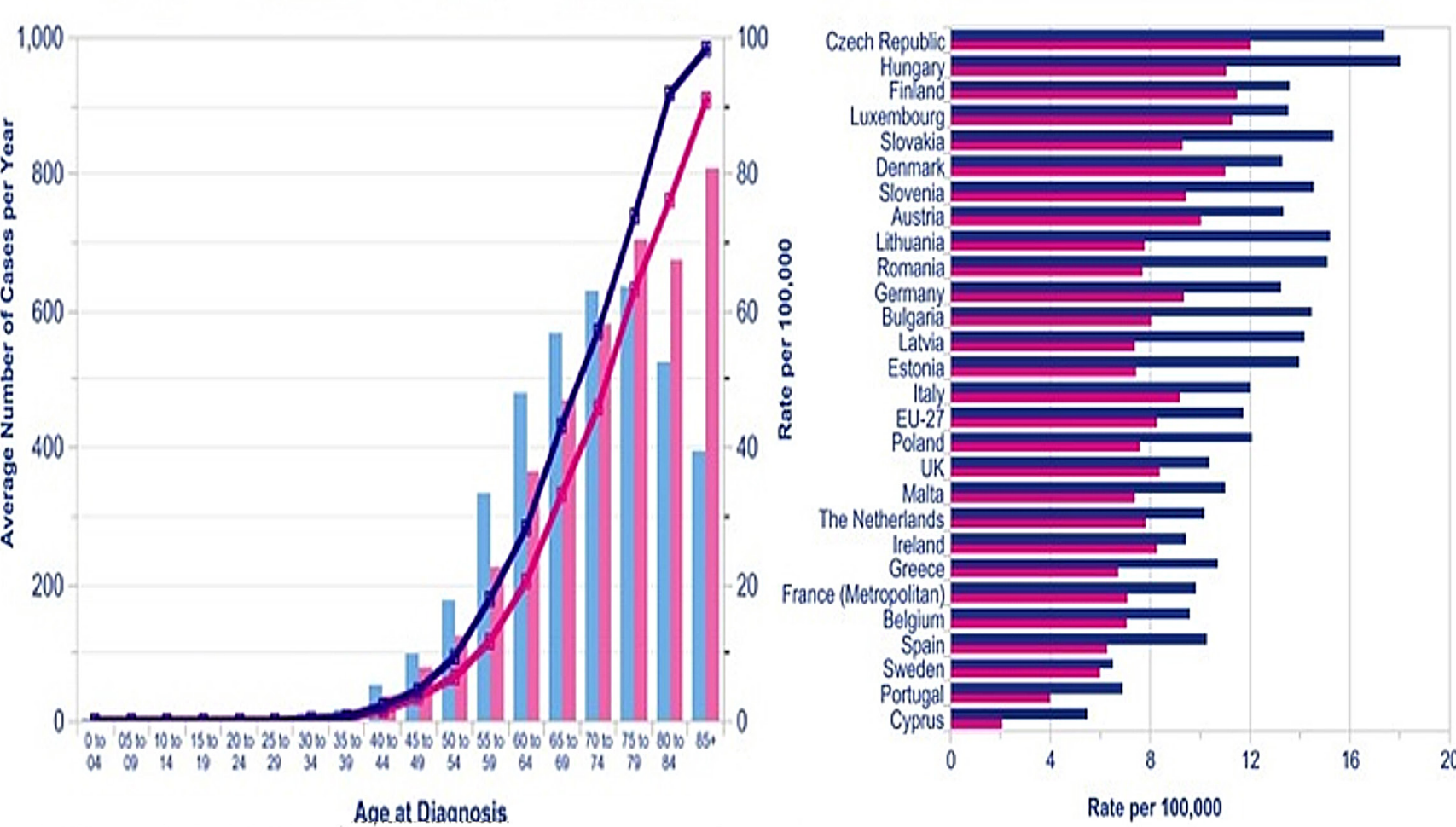

Fig. 2. $P C$ rates by age in the UK (A) and by nation in Europe (B). Modified from [8].

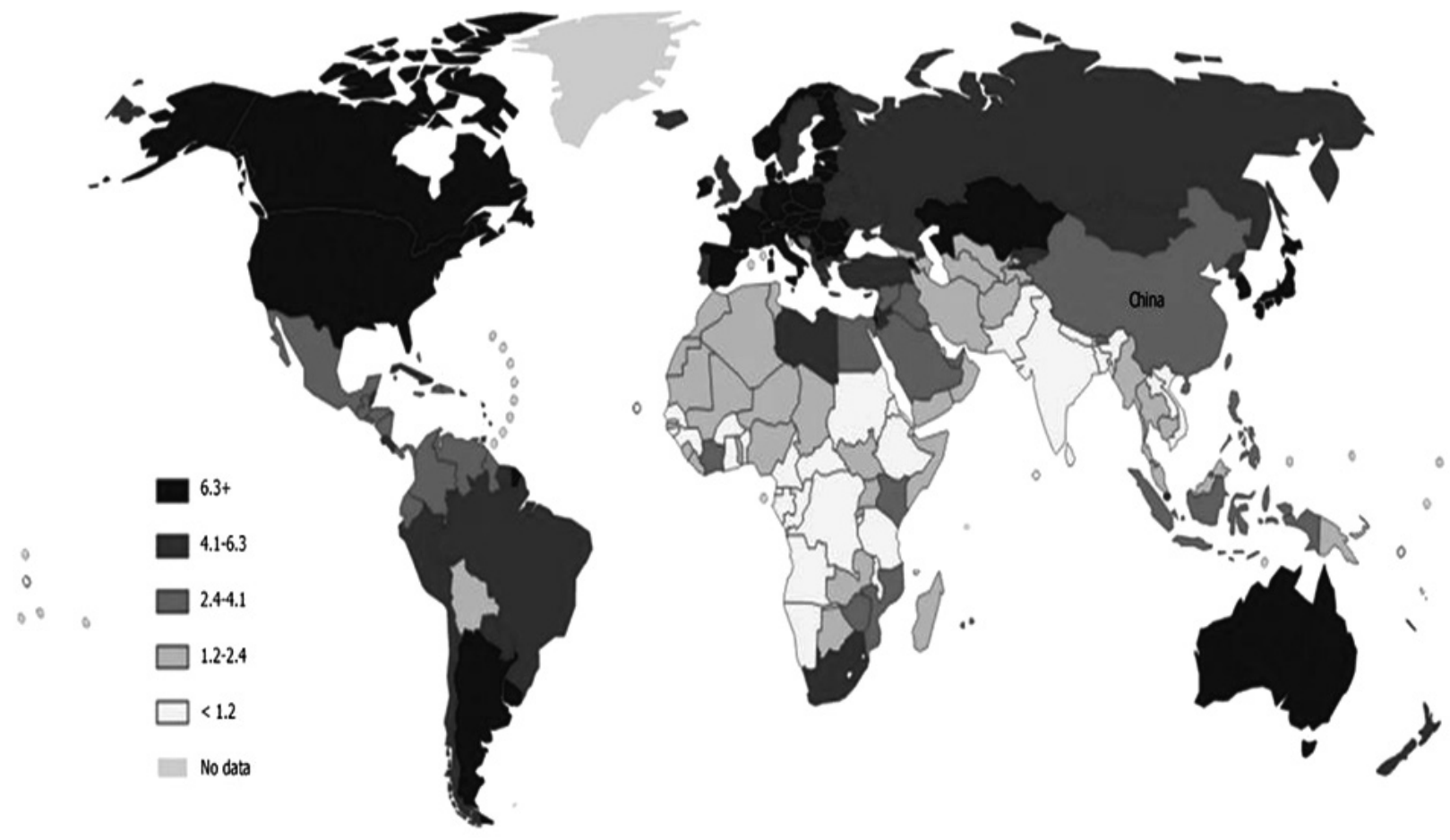

Fig. 3. The incidence rates of PC in the world according to IARC [9]. 


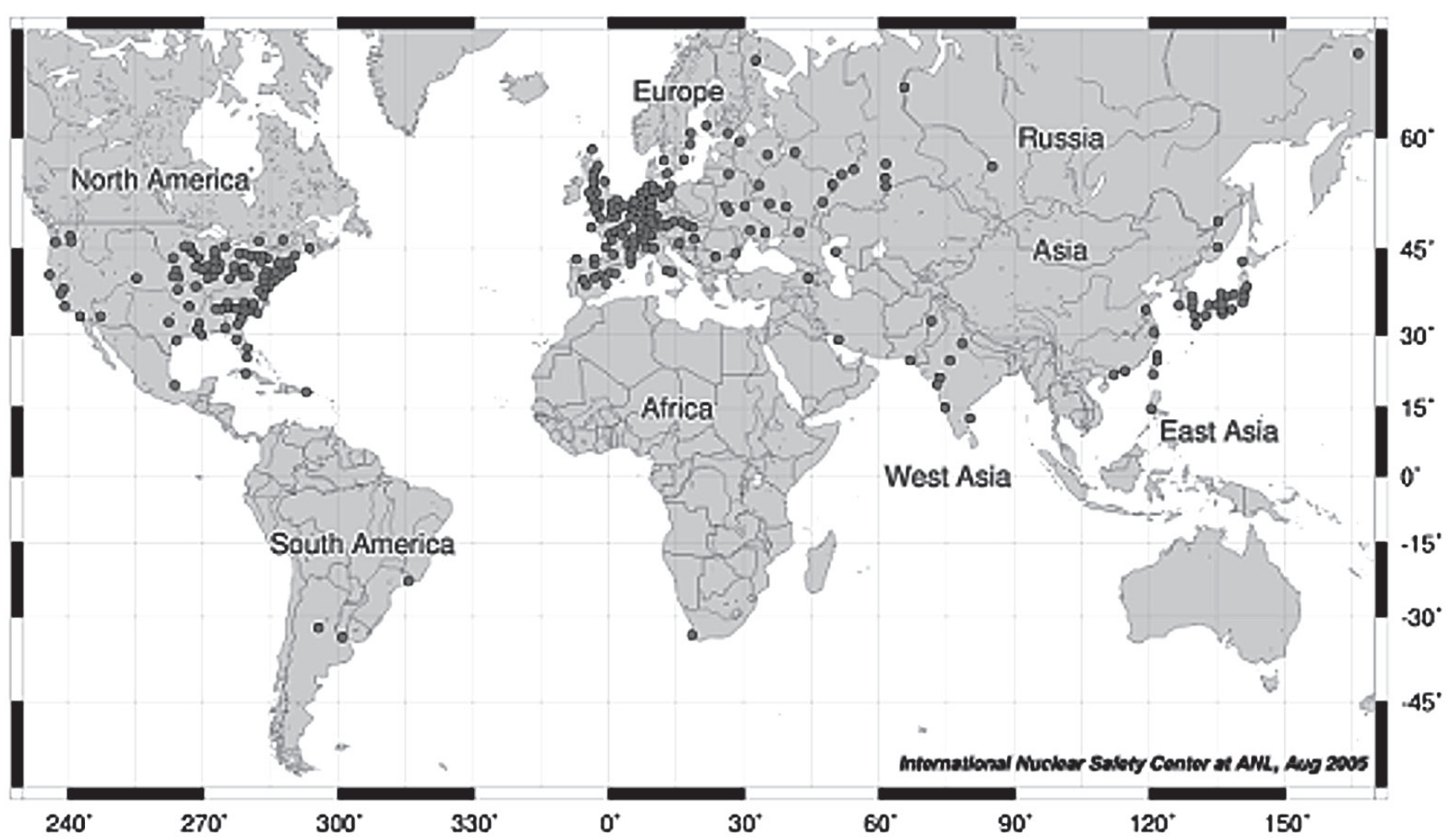

Fig. 4. The locations of nuclear power plants in the world (courtesy of the International Nuclear Safety Center [17, 22]).

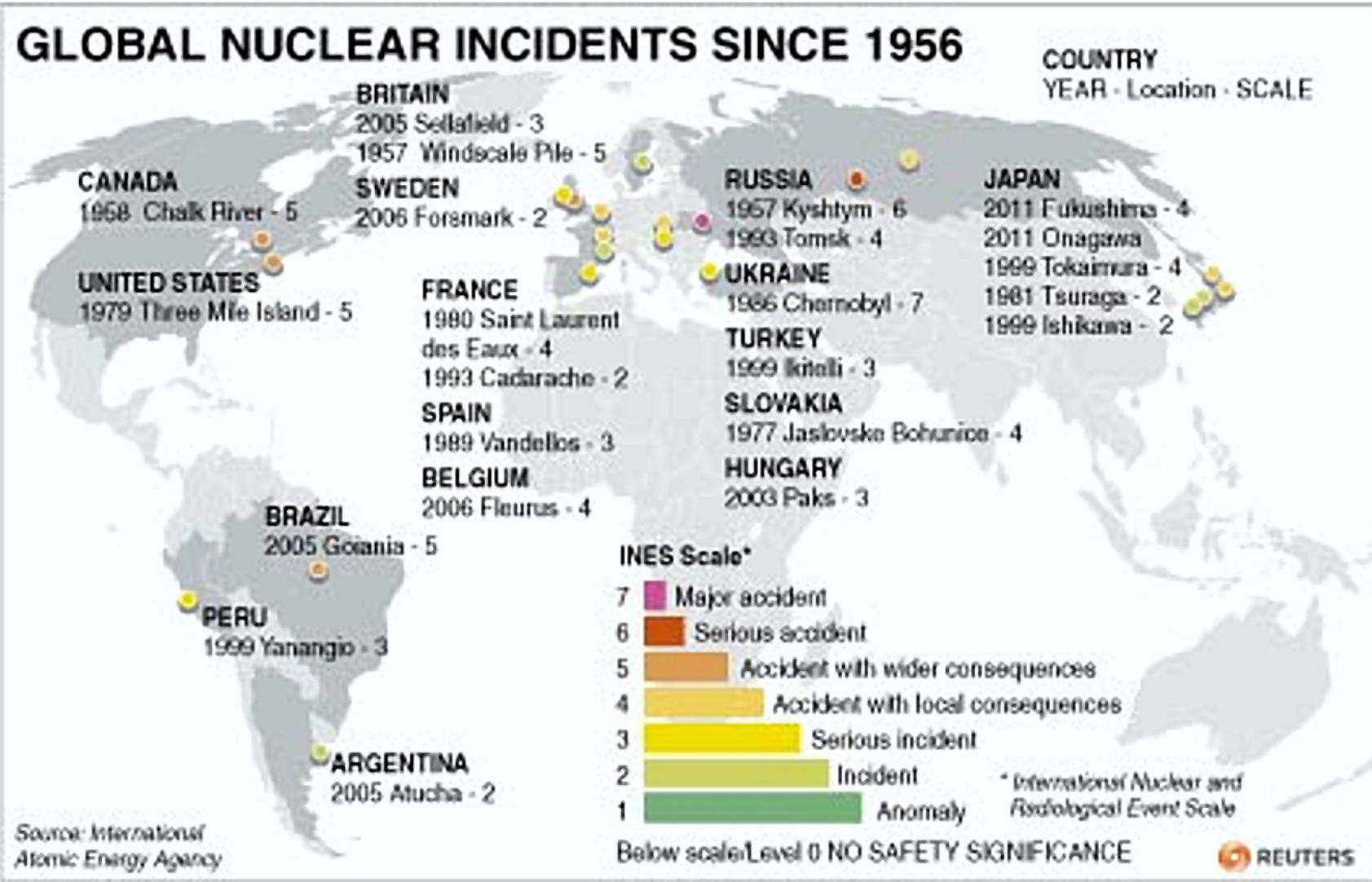

Fig. 5. Major nuclear accidents around the world (adapted from China Daily, 2017 [16]) 
is produced from anthropogenic sources and rapidly incorporated into the food chain. Cs is absorbed by plants competitively with potassium and in its radioactive form is the most dangerous radioisotope to the environment because of its long-term effects. Cesium-137 $\left({ }^{137} \mathrm{Cs}\right)$ halflive is about 30 years, which makes it present in the environment for about 300-600 years (Fig. 6). Iodine-131 may give a higher initial dose, but its short half-life of 8 days ensures that it will soon be gone. Iodine-131 remains in the environment for about 100 days. Cesium-137 decay by gamma and beta (electron) emissions produces highly ionizing radiation. Beta emission is very dangerous, when radioactive Cs is ingested because it deposits all energy in a very short distance in tissue by mimicking potassium chemical properties.

\section{Cesium in the pancreas}

The pancreas is a metabolically very active organ, which despite weighing only 80-100 grams in humans produces from 500 to $2000 \mathrm{ml}$ of pancreatic juice daily. The pancreas has a high blood perfusion from the pancreatic arteries and can accumulate inside the exocrine cells a considerable amount of radioactive Cs able to damage cell DNA. Pancreatic ductal adenocarcinoma (PC) has a very poor prognosis. Typically, only $24 \%$ of people survive 1 year after diagnosis, and $9 \%$ live for 5 years. Only $1-2 \%$ of pancreatic tumors are of the neuroendocrine type, being derived from the cells that produce pancreatic hormones. Such tumors are less aggressive compared with adenocarcinomas. In autoradiographic studies with mice (Fig. 7), Nelson et al. [20] showed that ${ }^{137} \mathrm{Cs}$ is concentrated in significant quantities in the pancreatic tissue, in particular in the exocrine cells, where most PCs (about 90\%) originate. In a mammalian organism, Nelson et al. [20] reported a differential selectivity for Cs in various organs (lower in liver and in fetuses). About $86 \%$ of adsorbed Cs is excreted in the urine by the kidney, and the remaining $14 \%$ is eliminated in the feces by secretions from the salivary glands and exocrine pancreas. In humans, the biological half-life of absorbed Cs varies from 50 to 150 days [15]. "Prussian Blue" (ferric ferrocyanide) is able to chelate Cs in the intestine and, by preventing its reuptake, eliminates it with feces [15]. Upon renal insufficiency in man and rat, cesium level increases by $100 \%$ in the pancreatic tissue [7]. In the counties of Sweden, Edling et al. [4] reported that low-dose background radiation exposure significantly correlates with PC (males, $r=0.59$; and, females, $r=0.40$ ).

The autoradiogram shows that, contrary to the common knowledge of many researchers (e.g. [15]), ${ }^{137} \mathrm{Cs}$ is not distributed in a homogeneous way within the body. Probably for this reason, the radiation damage differs in various Cs-concentrating organs, such as exocrine pancreas [2, 20,31], salivary glands and intestine [14]. Ingested ${ }^{137} \mathrm{Cs}$ also largely concentrates in the skeletal muscles. In Ukraine and in its neighbor country Belarus 20-30 years after Chernobyl, Bandazhevsky et al. [2], Zrielykh et al. [31], Leung et al. [14] and Krystle et al. [13] reported an increased incidence of PC and other tumors. ${ }^{137} \mathrm{Cs}$ concentrates in edible plants and fruit. In the Gomel region of Belarus, which was heavily contaminated by the fallout from the Chernobyl disaster, the damage of ${ }^{177} \mathrm{Cs}$ in organisms was studied of the rural population since 1990. Children have a higher average amount of ${ }^{137} \mathrm{Cs}$ than adults have [2]. In autopsies, the highest accumulation of ${ }^{137} \mathrm{Cs}$ was found in the endocrine glands, especially the thyroid, adrenal glands and pancreas. Bandazhevsky et al. [2] performed autopsies of six children who died from different causes in the polluted area near Chernobyl. It was found that ${ }^{137} \mathrm{Cs}$ level in the pancreas was $40-45$ times higher than in the liver (Table 1).

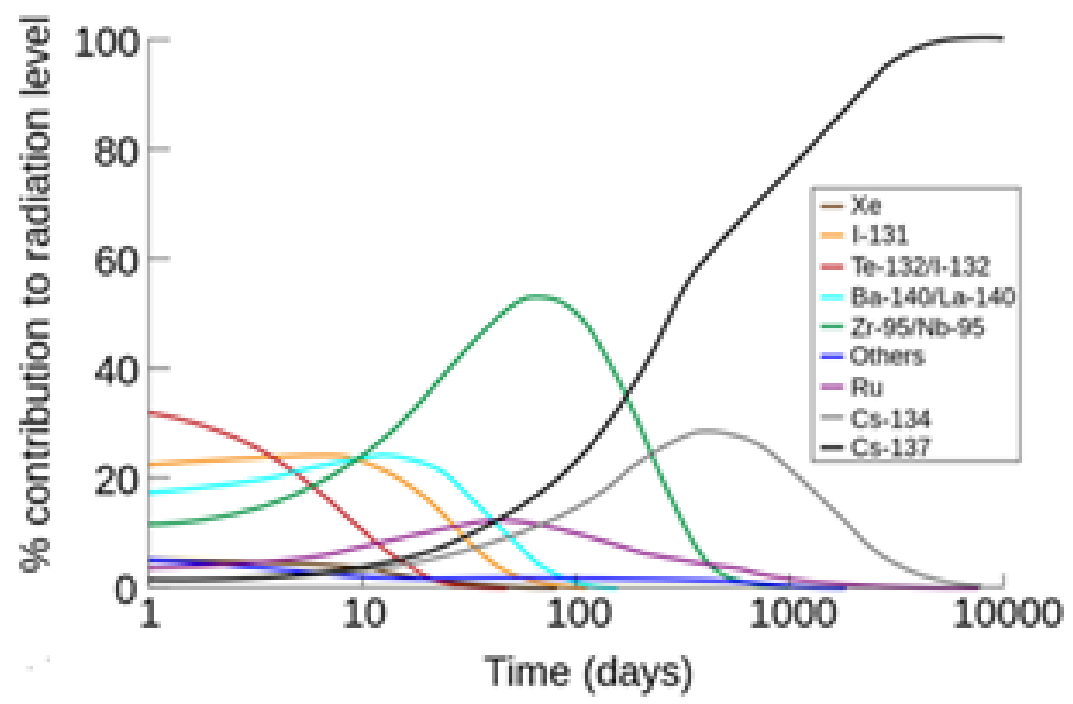

Fig. 6. The relative contributions of the major nuclides to the radioactive contamination of the air after an accident. Retrieved on 2009-0513 from https://web.archive.org/web/20070121042708/http:/atom.kaeri.re.kr 


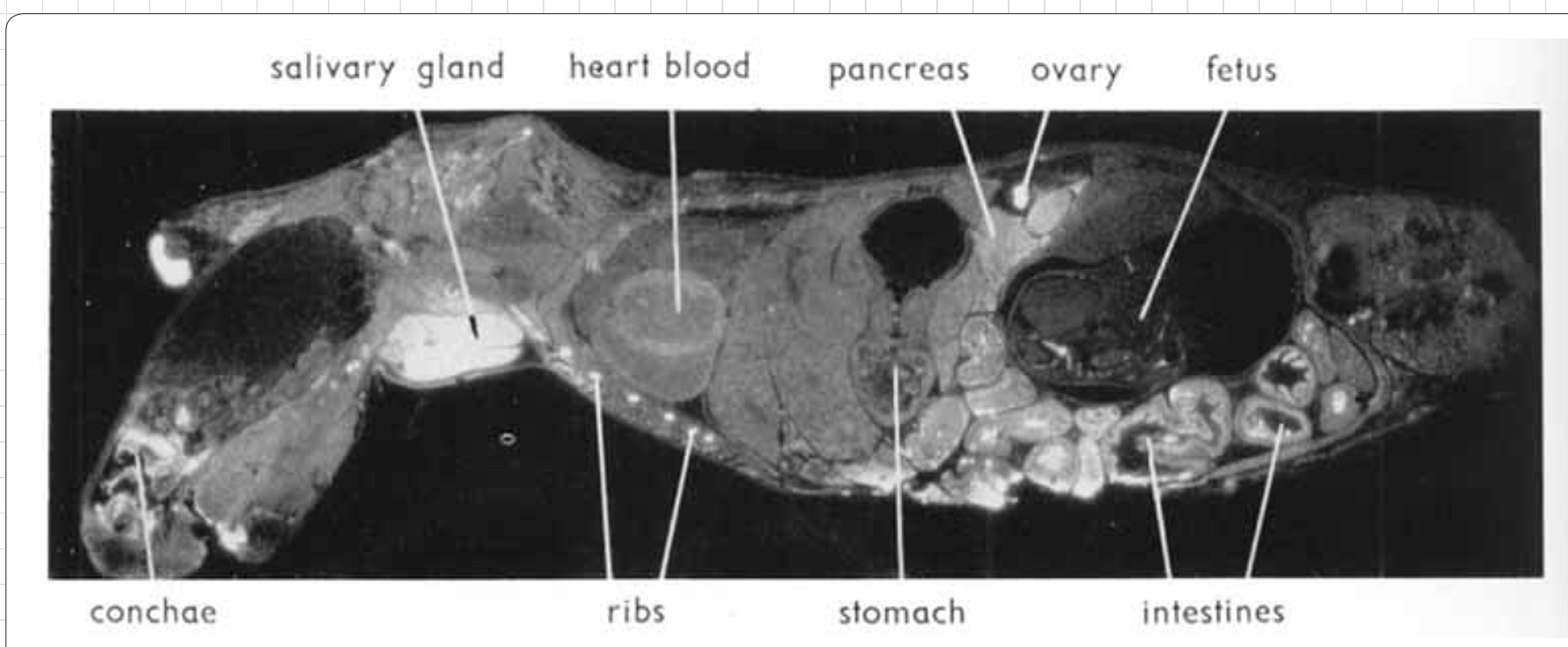

Fig. 7. Autoradiogram showing ${ }^{137} \mathrm{Cs}$ distribution in a pregnant mouse 6 hours after intravenous injection. White areas correspond to high radioactivity. Uptake is high in the salivary gland, pancreas and intestine. In fetuses, concentration is significantly lower than in the mother. In the pancreas, the islets of Langerhans appear to have a slightly lower activity than the acinar tissue. Reproduced with permission from [20].

${ }^{137} \mathrm{Cs}$ level in the organs of children exposed to Chernobyl fallouts (adapted from [2]).

\begin{tabular}{|c|c|c|c|c|c|c|}
\hline & 1 & 2 & 3 & 4 & 5 & 6 \\
\hline Cause of death & Sepsis & $\begin{array}{c}\text { Premature } \\
\text { malform. }\end{array}$ & $\begin{array}{c}\text { Sepsis } \\
\text { bleeding }\end{array}$ & $\begin{array}{l}\text { Cerebral } \\
\text { malform. }\end{array}$ & Cardiac & Sepsis \\
\hline \multicolumn{7}{|l|}{ Organ: } \\
\hline Hearth & 5333* & 4250 & 625 & 4166 & 1071 & 1491 \\
\hline Liver & 250 & 277 & 525 & 851 & 882 & 1000 \\
\hline Lung & 1125 & 2666 & 400 & 1195 & 1500 & 2610 \\
\hline Kidneys & 1500 & 1687 & 259 & 2250 & 812 & 583 \\
\hline Brain & 3000 & 1363 & 305 & 90 & 1693 & 714 \\
\hline Thyroid gland & 4333 & 6250 & 250 & 1900 & n.d. & 1583 \\
\hline Thymus & 3000 & 3833 & 1142 & 3833 & 714 & 833 \\
\hline Small intestine & 2500 & 1375 & 571 & 3529 & 2200 & 590 \\
\hline Large intestine & 3250 & 3125 & 261 & 3040 & 4000 & 2125 \\
\hline Stomach & 3750 & 1250 & 1500 & n.d. & n.d. & n.d. \\
\hline Spleen & 3500 & 1500 & 428 & 1036 & 2000 & 2125 \\
\hline Adrenals & 1750 & 2500 & n.d. & 2500 & 4750 & 2619 \\
\hline Pancreas & $\underline{11000}$ & $\underline{12500}$ & 1312 & n.d. $* *$ & n.d. & $\underline{2941}$ \\
\hline
\end{tabular}

Notes: * in bold are the highest levels found in other organs but the pancreas, and underlined are the cases when the pancreas features a still higher level; ** not determined. 


\section{C25 - Malignant neoplasn of pancreas}

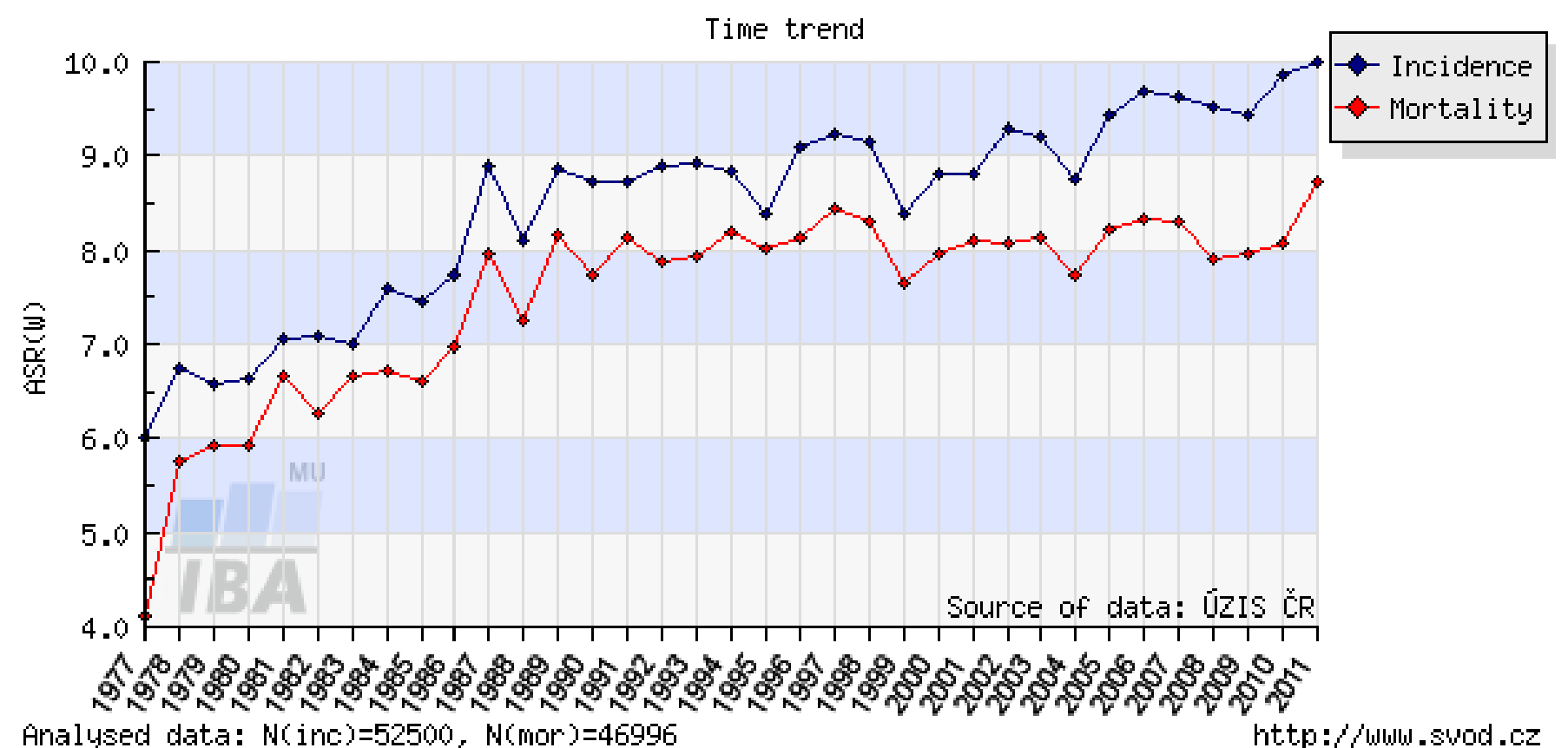

Fig. 8. Trends of PC incidence and mortality (1977-2011) in a country of Central-Eastern Europe particularly hit by the Chernobyl radioactive cloud. PC incidence and mortality rates in the Czech Republic (both sexes). Data source: CNCR [3].

\section{${ }^{137}$ Cs vs. PC in Europe}

In the early 1970 s, mortality from PC was low in Europe, stomach cancer being among the leading causes of cancer death. Nowadays, after about 50 years, the trends in these cancers are reversing [29]. Since the probable PC latency is of about 8 years, it is likely that the radioactive fallouts of the numerous nuclear tests that were carried out mainly in the years 1960-1985 and from accidents or nuclear fuel depletion of ships and atomic submarines may have been important in its increase (Fig. 8). According to the International Atomic Energy [11], the radioactivity, with consequent fallout, released into the atmosphere from nuclear weapons testing was far greater than that from nuclear accidents: about 400 peta-Bequerels (PBq) versus $85 \mathrm{PBq}$ from Chernobyl, and 10-30 PBq from Fukushima. PC increase largely begins in the early 1980s and, in Europe, after the 1986 Chernobyl accident $[8,10]$.

\section{${ }^{137}$ Cs vs. PC in Italy}

In Italy, the incidence of PC is growing significantly (+ $0.4 \%$ annually), with a clear North-to-South gradient: compared to the northern Italy, in the central Italy PC incidence levels are 29\% lower in males and 26\% lower in females, and the southern Italy, they are $25 \%$ and $28 \%$ lower respectively. PC ranking among the causes of death from tumors is $4^{\text {th }}$ in females, the total $(\mathrm{M}+\mathrm{F}) \mathrm{PC}$ mortality being $6 \%$. These data correlate with the current exposure to ${ }^{137} \mathrm{Cs}$ in Italy (Fig. 9).

High ${ }^{137} \mathrm{Cs}$ is associated with high altitude. In the mountains, rainfalls enhance radioactive fallouts. In the mountainous Northern Italy (Alps) and in the hilly Central Italy (Apennines), PC incidence is higher than in the Southern Italy and in islands, where PC mortality compared to that in the Northern Italy is $-29 \%$ in males and $-26 \%$ in females respectively (Table 2). In Italy, the radioactive cloud of Chernobyl also hit more the Northern part because the cloud came from Northern Europe and reached about the half of Italy, while Southern Italy was almost completely spared [21].

Traces of the radioactive elements released by the 1986 Chernobyl accident are still present at higher levels in the Northern Italy, Alsace, Eastern France and Southern Germany, while the traces of nuclear tests from the 1960s are more evenly distributed, with peaks in the central southern France, in the Massif Central region, in the Ardennes area, and in Brittany. However, according to some experts, these concentrations are not harmful for the environment and population. The highest levels of ${ }^{137} \mathrm{Cs}$ are found on the surface layers of the soil, from where they are absorbed by plants, fruit and fungi and enter the food chain, and finally, in the human and predatory animal bodies, where environmental ${ }^{137} \mathrm{Cs}$ undergoes greater and more harmful bioaccumulation. 


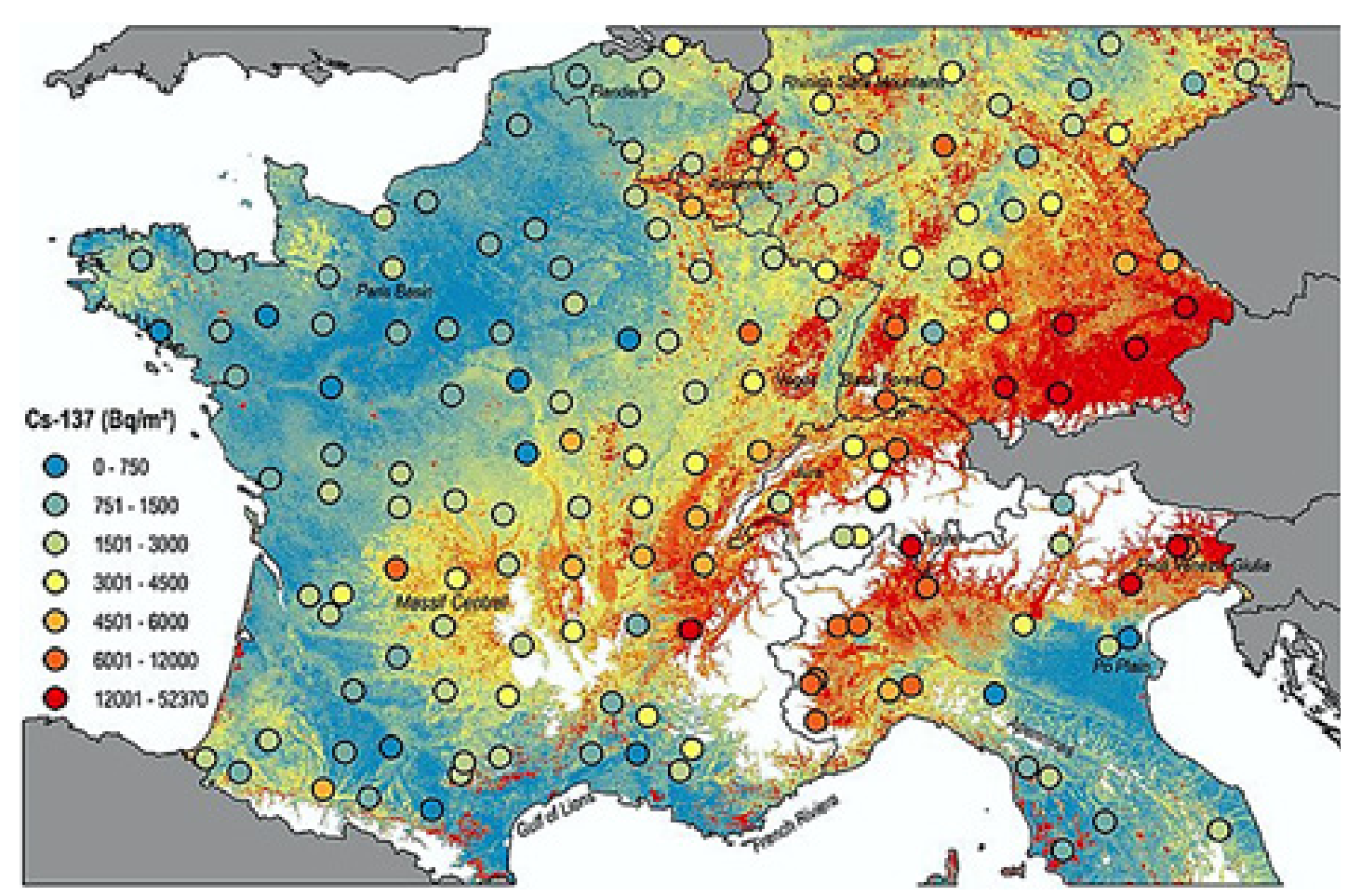

Fig. 9. The new map of Cesium-137 contamination in Europe (adapted from [18]).

PC incidences per 100000 populations in different parts of Italy*

\begin{tabular}{|l|c|c|c|c|c|}
\hline & \multicolumn{3}{|c|}{ Incidence } & \multicolumn{2}{c|}{ Difference of III from: } \\
\hline & I. North & II. Center & III. South and islands & I & II \\
\hline M & 24.6 & 18.9 & 17.5 & $-23 \%$ & $-29 \%$ \\
\hline F & 18.3 & 15.7 & 13.6 & $-14 \%$ & $-26 \%$ \\
\hline
\end{tabular}

* Based on data available from Associazione Italiana di Oncologia Medica [21].

\section{${ }^{137}$ Cs from Chernobyl vs. PC}

The accident took place on 26 April 1986; some 10-20 million people were exposed to significant levels of fallout; several hundred workers at the plant received whole-body radiation, 134 developed acute radiation sickness and, of these, 28 died within four months. However, what longterm effects did the accident produce? In Belarus, almost exactly half the cases occurred in the region that is closest to Chernobyl, which received the highest fallout. The world incidence of childhood thyroid cancer can be assumed as approximately $1 /$ million children/year, but in Belarus as a whole, the incidence by 1995 was almost 30-fold higher, and, in Gomel Region, it reached approximately 100/million children/year [30]. Very large quantities of radioactive iodine and a considerable amount of ${ }^{137} \mathrm{Cs}$ have been discharged into the atmosphere [11, 27, 30] (Figs. $10,11)$.
In 2000, Moseman [19] reported that meat of over 1000 wild bears killed in Germany in the previous year was contaminated with ${ }^{137} \mathrm{Cs}$ from Chernobyl, with over 600 Becquerel allowed per kg of meat. In 2009, Puschmann [23] reported that, in Norwegian cattle and sheep, ${ }^{137} \mathrm{Cs}$ after the Chernobyl accident is expected to be detectable for over 100 years to come. The Norwegian Food Safety Authority ordered the farmers to feed their animals with safer food, if radioactivity is too high. Animals can be also fed with the cesium chelator Giesesalt (also called "Berlin blue"), which binds the radioactive $\mathrm{Cs}$ and then excretes it from the body [23]. ${ }^{137} \mathrm{Cs}$ is a major health problem in contaminated areas near the radioactive wreck at the Fukushima nuclear power plant. In 2016, social scientists and energy policy experts have reported that worldwide there have been 99 accidents at nuclear power plants from 1952 to 2009 [26]. Therefore, ${ }^{137} \mathrm{Cs}$ is still well detectable in Europe [11], and although it is 


\section{Distribution of selected radioactive material released after Chernobyl}

Cumulative iodine-131 air concentration in May $1986\left(\mathrm{~Bq} * \mathrm{~d} / \mathrm{m}^{3}\right)$

Deposition of caesium-137 $\left(\mathrm{kBq} / \mathrm{m}^{2}\right)$
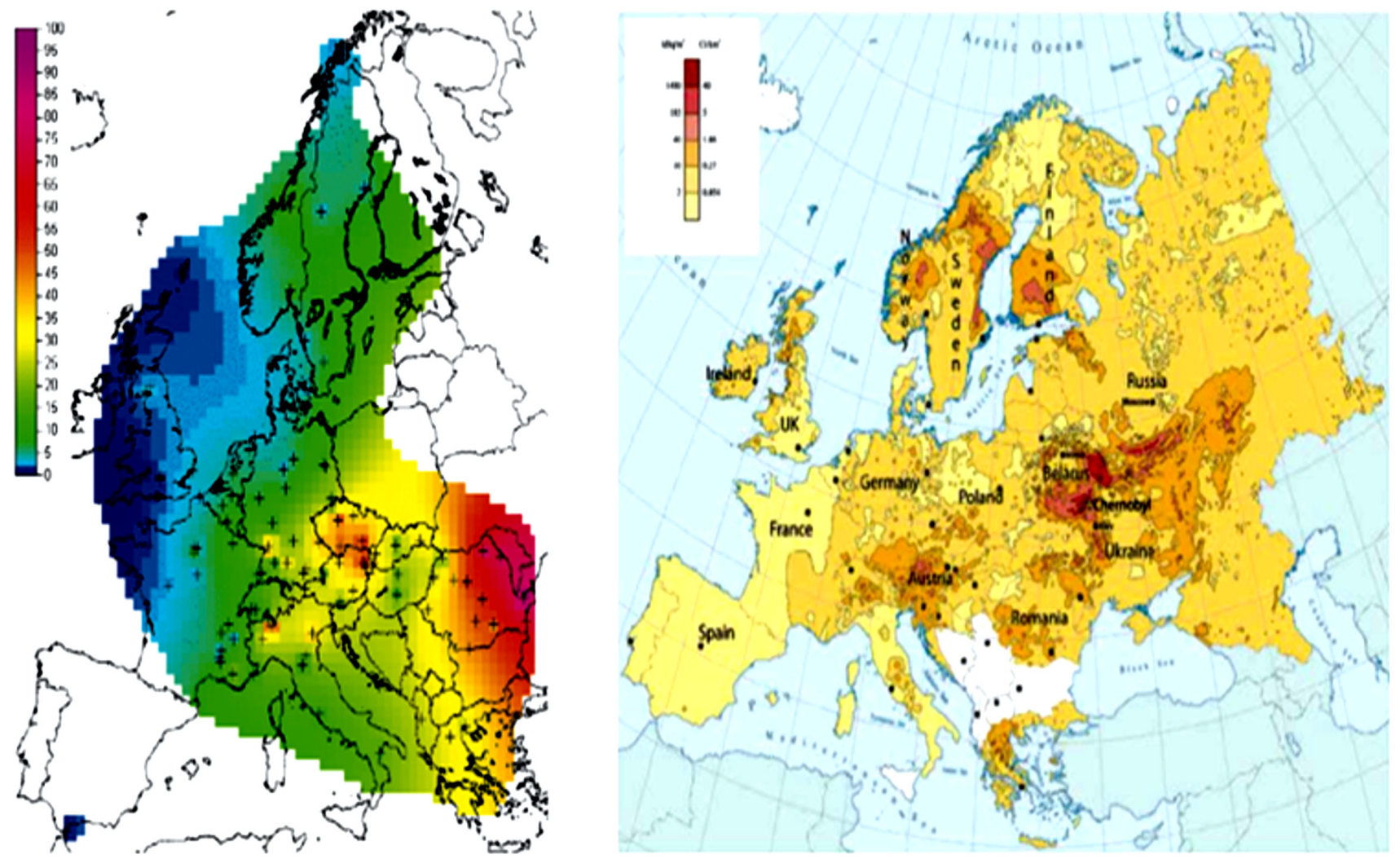

Data source: TORCH 2016, based on data from the European Commission Joint Research Centre; UNSCEAR, based on De Cort et al., 1998.

Fig. 10. Distribution of the Chernobyl radioactive cloud in Europe.

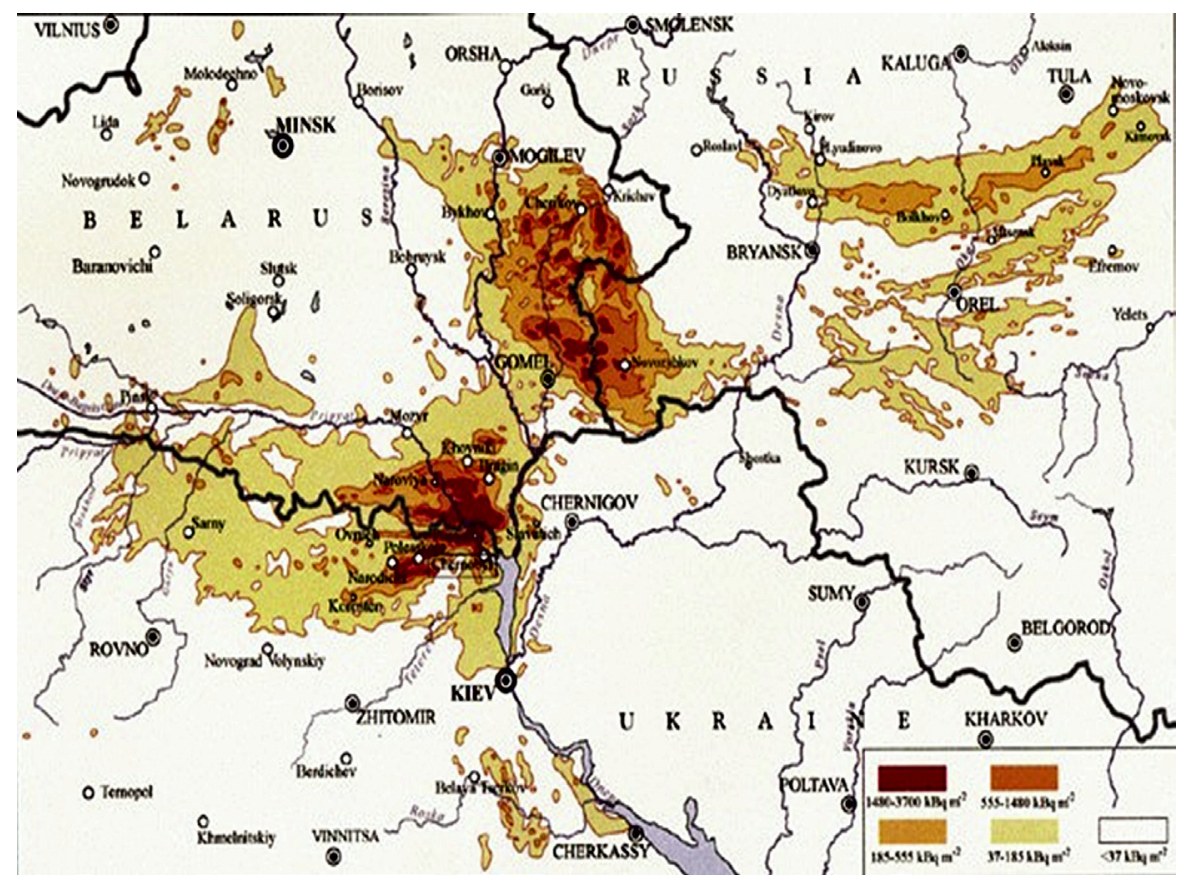

Fig. 11. Nuclear fallout from the Chernobyl accident (1986) in Ukraine, Belarus, and Russia (adapted from [30]). 
present in trace amounts considered not harmful by current experts, nobody really knows the cumulative damage that it can cause over time! ${ }^{137} \mathrm{Cs}$ is excreted in the urine over the course of months or years, and this is more than long enough to cause liver, pancreatic and other cancers [12]. The release of radionuclides into European atmosphere had effects on environment and health. Agricultural and natural ecosystems in Belarus, Russia and Ukraine, as well as in many other European countries, were affected as radionuclides were taken up by plants, fruit and later by animals and found in milk, meat, forest food products, freshwater fish. The impact of the Chernobyl fallout on human health is not unanimously agreed by experts; indeed United Nations agency conclusions are challenged. The effects of heavy fallout exposure include radiation sickness and cataracts, with thyroid cancer, especially in children and adolescents, and leukemia [2].

In 2020, Zrielykh reported [31] that in Ukraine, there is an important tendency of an increase in PC incidence and mortality rates. The number of PC cases increased by $8.7 \%$ (7.3\% in men and $10.3 \%$ in women) in 2013 in comparison with 2003. PC incidence in children (age 0-17 years) was zero in 2003 and 4 in 2013. Age-standardized PC incidence rate was 5.9 in 2003 (8.6 in men; 4.0 in women) and 6.8 in 2013 (9.8 in men; 4.7 in women). Agestandardized mortality rate was 5.0 in 2003 (7.4 in men; 3.4 in women) and 5.5 in 2013 (7.9 in men; 3.9 in women). It should be noted that, in 2013, four children had PC, whereas normally in the rest of the world children are rarely affected.

\section{CONCLUSION}

The above analysis of PC epidemiology may be the key to interpreting the etiology of PC and thus, the cornerstone of developing a possible effective prevention strategy. The reported data warrant investigations into a possible association between radioactive cesium and PC. If this correlation will be confirmed, a preventive action may be possible by using table salt enriched in potassium and by a diet rich in fruits and vegetables that feature the highest levels of potassium. These and other foods should be derived mainly from the southern territories of the nations that by now are generally the least polluted by radioactive elements. In cases of occasional strong accidental ingestion of radioactive Cs, "Prussian Blue" will be indicated.

Conflict of interest: There are no conflicts of interest.

\section{References}

1. American Cancer Society. Cancer Facts \& Figures. Atlanta; 2019.

2. Bandazhevsky YI. Chronic Cs-137 incorporation in children's organs. Swiss Med Wkly. 2003;133(35-36):488-90.

3. Dušek L, Vyzula R, Melichar B, Abrahámová J, Fínek J, Petruželka L, Vorlíček J. Číselné podklady pro plánování nákladů léčebné péče v onkologii, analýzy dostupných populačních dat a predikce pro rok. In: Modrá Kniha České Onkologické Společnosti. Brno: Masarykův Onkologický Ústav; 2014. P:254-97. (In Czech)

4. Edling C, Comba P, Axelson O, Flodin U. Effects of low-dose radiation - a correlation study. Scand J Work Environ Health. 1982;8(Suppl 1):59-64.

5. Environmental Protection Agency Bulletin. HyperPhysics; 2017.

6. Ferlay J, Soerjomataram I, Ervik M, Dikshit R, Eser S, Mathers C, Rebelo M, Parkin D.M, Forman D, Bray F. GLOBOCAN 2012. Cancer Incidence and Mortality Worldwide. IARC Cancer Base No. 11. International Agency for Research on Cancer, Lyon (France); 2013.
7. Gawlik D, Behne D, Kraft D, Offermann G. The influence of renal insufficiency on caesium metabolism in man and rat (with a note on the Cs content of some biological standard materials). J Trace Elem Electrolytes Health Dis. 1989;3(1):4350.

8. GBD 2017. Pancreatic Cancer Collaborators. The global, regional, and national burden of pancreatic cancer and its attributable risk factors in 195 countries and territories, 1990-2017: a systematic analysis for the Global Burden of Disease Study. Lancet Gastroenterol Hepatol. 2019; 4(12):934947. doi:10.1016/S2468-1253(19)30347-4.

9. IARC Monographs on the Evaluation of Carcinogenic Risks to Humans: Volume 100D. http://monographs.iarc.fr/ENG/Monographs/ vol100D/.

10. Institute of Health Information and Statistics of the Czech Republic: Czech National Cancer Registry (CNCR). http://www.uzis.cz/registry-nzis/nor .

11. International Chernobyl Project Technical Report. International Atomic Energy Agency, Vienna; 1991. 
12. Kluger J. Japan's Radiation Exposure: How Serious Is It? Time, March 12, 2011.

13. Leung KM, Shabat G, Lu P, Fields AC, Lukashenko A, Davids JS, Melnitchouk N. Trends in solid tumor incidence in Ukraine 30 years after chernobyl. J Glob Oncol. 2019(5):1-10. doi:10.1200/jgo.19.

14. Lestaevel P, Racine R, Bensoussan H, Rouas C, Gueguen Y et al. Césium 137: propriétés et effets biologiques après contamination interne [Caesium 137: Properties and biological effects resulting of an internal contamination]. Médecine Nucléaire. 2010;34(2):108-18. (in French)

15. Major nuclear accidents around the world. China Daily, 17-3-2017. http://www.chinadaily.com.cn/ world/2011-03/17/content_12185169.htm

16. Map of Nuclear Power Plants Showing the Location of the World's Nuclear Power Plants. International Nuclear Safety Center; 2015

17. Meusburger K. The new map of Cesium-137 radioactive contamination in Europe. Scientific Reports, Basel; 2020.

18. Moseman A. 24 Years After Chernobyl, Radioactive Boars Still Roam Germany. Discover magazine; 2010. https://www.discovermagazine.com/ environment/24-years-after-chernobyl-radioactive-boars-still-roam-germany

19. Nelson A, Ullberg S, Kristoffersson H, Ronnback C. Distribution of radiocesium in mice. Acta Radiol. 1961;55:374-84.

20. Numeri del Cancro in Italia. Associazione Italiana di Oncologia Medica; 2018. https://www.ars.toscana.it/images/2018_NumeriCancro-operatori.pdf.

21. Pogharian A. Map Monday, Where are the world's nuclear power plants? Interweaving Mythology,
Science, \& History. August 24, 2015. http://www. armenpogharian.com/map-monday-where-arethe-worlds-nuclear-power-plants/

22. Puschmann O. Fortsatt nedforing etter radioaktivitet i dyr som har vært på utmarksbeitein. Eksterne lenker; Matportalen-radioaktitivitet; 2009. (In Norwegian) https:/qa.landbruksdirektoratet.no/ no/erstatning/palegg-og-restriksjoner/radioaktivitet/fortsatt-nedforing-etter-radioaktivitet-i-dyr-som -har-v\%C3\%A6rt-p\%C3\%A5-utmarksbeite

23. Rawla P, Sunkara T, Gaduputi V. Epidemiology of pancreatic cancer: Global trends, etiology and risk factors. World J Oncol. 2019;10(1):10-27.

24. Rosenzweig A. New Global Cancer Statistics Released. Pancreatic Cancer Action Network; 2018. https://www.pancan.org/facing-pancreaticcancer/

25. Sovacool BK, Brown MA,Valentine SV. Fact and Fiction in Global Energy Policy: Fifteen Contentious Questions. Baltimore: Johns Hopkins University Press; 2016.

26. UNSCEAR 2000 Report, Vol. 2, Annex J. United Nations, New York and Geneva; 2000.

27. U.S. Food and Drug Administration (F.D.A.), Radiation Emergencies. CDC. 20 Oct 2013.

28. Venturi S, Venturi M. Iodide, thyroid and stomach carcinogenesis: evolutionary story of a primitive antioxidant? Eur J Endocrinol. 1999;140(4):371-2.

29. Williams D. Cancer after nuclear fallout: lessons from the Chernobyl accident. Nat Rev Cancer. 2002;2:543-9.

30. Zrielykh L. Analysis of statistics of pancreatic cancer in Ukraine for a period of 10 years. J Clin Oncol. 2020;38(15_suppl), e16721-e16721.doi:10.1200/ JCO.2020.38.15_suppl.e16721

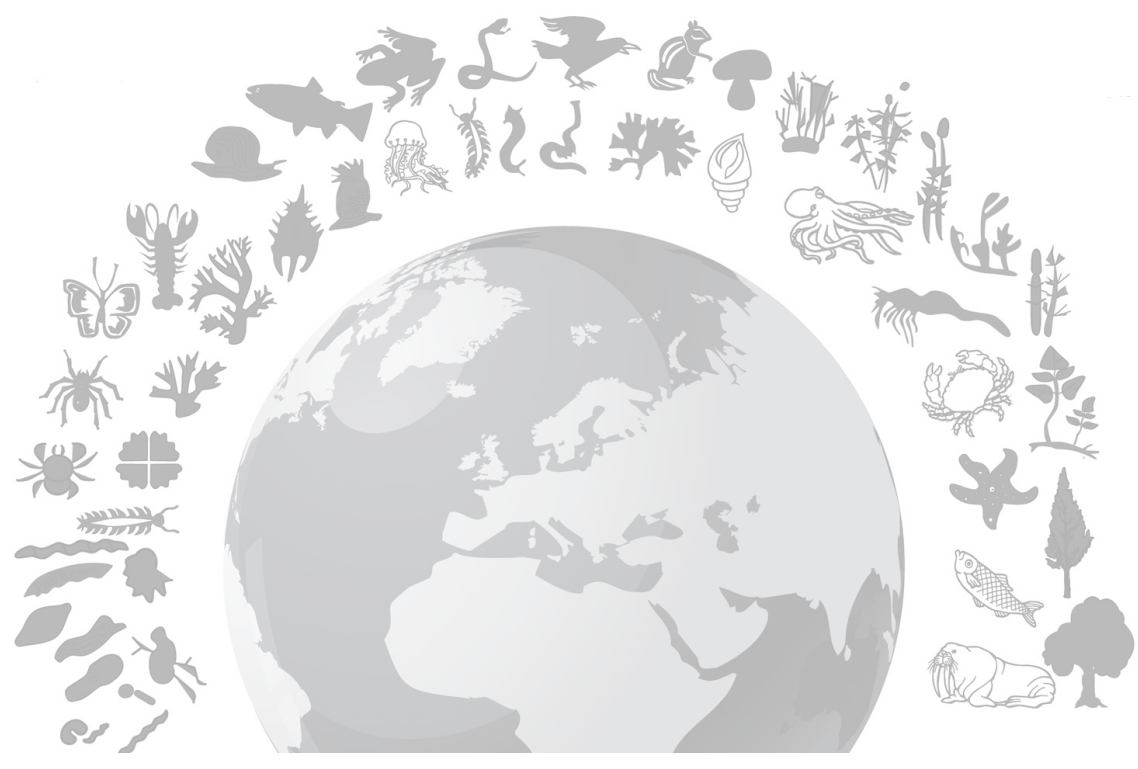

